\title{
Spatial Diversity Characterising Certain Chemical Substances in Sediments of Besko Reservoir
}

\author{
Dorota Piwińska', Renata Gruca-Rokosz", Lilianna Bartoszek', Joanna Czarnota' \\ 1 Department of Environmental Engineering and Chemistry, Rzeszow University of Technology, Powstańców \\ Warszawy 6, 35-959 Rzeszów, Poland \\ * Corresponding author's e-mail: renatagr@prz.edu.pl
}

\begin{abstract}
The article reports the conducted analyses of certain chemical parameters characterising the sediments of Poland's Besko Reservoir. Specifically, determinations concerned the $\mathrm{pH}$ value, percentage organic matter (OM), total organic carbon (TOC), total nitrogen (TN), carbonates $\left(\mathrm{CO}_{3}^{2-}\right)$, total phosphorus (TP) and its fractions, as well as heavy metals ( $\mathrm{Fe}, \mathrm{Al}, \mathrm{Cr}, \mathrm{Cu}, \mathrm{Ni}, \mathrm{Cd}, \mathrm{Zn}, \mathrm{Mn}$ ). The sediments have a slight alkaline reaction, with $\mathrm{pH}$ values correlating positively with the high content of carbonates. The sediments have low organic matter content, while organic carbon accounts for about $30 \%$ of OM. The values for the C:N ratio point to an allochthonous origin for organic matter. The analysis of phosphorus fractionation showed that inorganic phosphorus (IP) is predominant at every research station. The lowest percentage for a fraction was in turn obtained for NAIP. This testifies to a slight anthropogenic impact of the catchment area. The sediments can be classified as of the $2^{\text {nd }}$ purity class (according to PIG), due to their highest concentration of chromium. According to Müller's classification, the sediments can be classified as purity class 3 (i.e. with moderate contamination). The values noted for the EF coefficient confirm a very strong enrichment by chromium ions. In addition, chromium, copper, nickel and cadmium have a negative effect on aquatic organisms. The results show that the sediments can be used for example in building and maintaining hydraulic structures.
\end{abstract}

Keywords: sediments, organic matter, phosphorus, heavy metals

\section{INTRODUCTION}

Bottom sediments are among the most important components of aquatic ecosystems. They participate in the circulation of matter, being places in which the chemical transformation, deactivation and decomposition of chemical substances occur. The products of these processes reach the water, while sediments store diverse chemical contaminants, including toxic ones. Under favourable conditions, the latter may also be released into the water, with the result being the so-called secondary pollution of aquatic ecosystems. Nevertheless, the content of hazardous substances is many times higher in sediments than in water. It is possible to detect and observe the changes in the quantity of contaminants, while the chemical composition of the sediment proves to be a better indicator of water pollution than the chemical composition of water itself. The chemical composition of water proves to be variable over time [Szarek-Gwiazda 2013], with reservoirs being particularly exposed to various types of contaminants. The latter reach the aquatic environment, given the low-point locations of reservoirs, a fact that also ensures that sediments can provide the necessary knowledge on the impact of human activity on the aquatic environment. The knowledge of the physical and chemical properties of sediments is an essential source of information that can be used to assess the degree of degradation in reservoirs. It is also necessary if a concept regarding potential reclamation activities is to be developed.

The aim of the work described here has thus been to analyse selected chemical parameters in sediments in the case of Besko Reservoir. 


\section{RESEARCH AREA AND METHODOLOGY}

\section{Research area}

Besko (or Sieniawski) Reservoir is an artificial body of water located in Sieniawa in Poland's Podkarpackie Voivodeship (Province-Region). It was established in 1978 along the River Wisłok, by means of a dam which is $174 \mathrm{~m}$ long, $38 \mathrm{~m}$ high and $7.5 \mathrm{~m}$ wide. Thanks to the dam, the waters of the Wisłok are impounded to a height of 30 m [http://www.krakow.rzgw.gov.pl].

The purpose of the construction was to supply drinking water to the nearby towns of Rymanów, Iwonicz, Krosno and Brzozów. Howev- er, the reservoir is also used to generate energy, while helping to safeguard against flooding in the Wisłok Valley and in general evening out flows along the part of that river below the dam [http://www.krakow.rzgw.gov.pl].

\section{Research methodology}

In July 2016, sediments samples were collected using a gravity sampler (KC Kajak), at four research stations the locations of which are given, along with morphometric parameters of the Reservoir, in Figure 1.

The uppermost $5 \mathrm{~cm}$ layer of sediment was collected for analysis. The sampled sediments

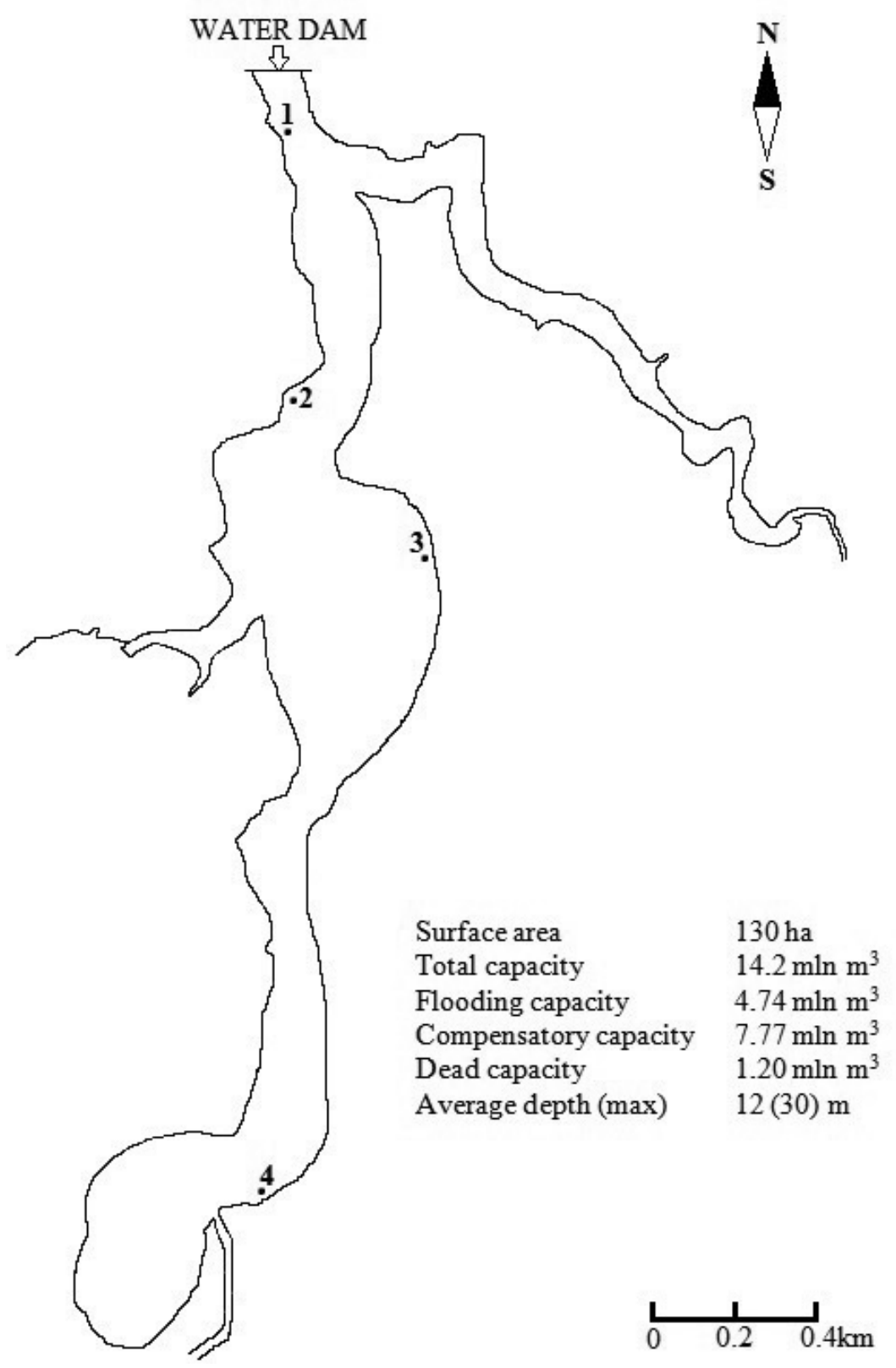

Figure 1. Besko Reservoir - research stations (1, 2, 3, 4), morphometric parameters of the Reservoir 
then dried to a constant weight at room temperature, and subsequently at $60^{\circ} \mathrm{C}$. The sediments were milled, prior to determinations being made for such parameters as $\mathrm{pH}$, percentage of organic matter $(\mathrm{OM})$, total organic carbon (TOC), total nitrogen (TN), carbonates $\left(\mathrm{CO}_{3}{ }^{2-}\right)$ and total phosphorus (TP), as well as the metals $\mathrm{Fe}, \mathrm{Al}, \mathrm{Cr}, \mathrm{Cu}$, $\mathrm{Ni}, \mathrm{Cd}, \mathrm{Zn}$ and $\mathrm{Mn}$.

The OM content was determined as the loss after drying of sediments within $4 \mathrm{~h}$ at $550^{\circ} \mathrm{C}$. The reaction was determined potentiometrically (MultiLine P4, WTW, Germany) in slurry with $1 \mathrm{~N}$ $\mathrm{KCl}$ [Ostrowska et al. 1991]. The carbonate content was measured by volume using a Scheibler apparatus, while the contents of TOC and TN were determined at $1020^{\circ} \mathrm{C}$ using a $\mathrm{CN}$ elemental analyzer (Flash EA 1112, ThermoQuest). The quality analysis made use of the standard samples of known amounts of carbon and nitrogen (sulfanilamide $-\mathrm{C}_{6} \mathrm{H}_{8} \mathrm{~N}_{2} \mathrm{O}_{2} \mathrm{~S}$ ). Prior to determination of TOC content, the dried and grinded sediment samples were placed in a desiccator with concentrated $\mathrm{HCl}$ vapor [Zimmermann et al. 1997] for $72 \mathrm{~h}$, to ensure the removal of carbonates. Prior to analysis, the sediment sample was again dried to constant weight at $60^{\circ} \mathrm{C}$.

Sediment was mineralised for the determinations involving TP and heavy metals. For this purpose, $0.5 \mathrm{~g}$ of sediment was placed into each Teflon vessel, with $10 \mathrm{~cm}^{3}$ of concentrated, spectrally pure nitric acid added afterwards. The samples were placed into a MARS 6 Microwave Digestion System, and mineralised using microwave energy at 1600 watts for $40 \mathrm{~min}$. (temperature rise time -15 minutes, soaking time -25 minutes), at $180^{\circ} \mathrm{C}$. After cooling, mineralisates were filtered through quantitative paper filters, and additionally by syringe filters. TP was obtained using the spectrophotometric method (Thermo Spectronic spectrometer, United Kingdom), whereas heavy metals were determined using a plasma emission spectrometer (ICP-OES GBC Quantima E 1330).

Phosphorus fractionation analysis was carried out in line with the Standards Measurements and Testing (SMT) protocol. Thus, an appropriate distinction between organic and inorganic forms of phosphorus can be drawn. The fractions obtained are inorganic phosphorus, organic phosphorus (OP), apatite phosphate (AP, calcium-bound forms) and non-apatite inorganic phosphorus (NAIP; Al, Fe and Mn oxides and hydroxides forms) [Ruban et al. 2001]. The analysis of phosphorus forms was performed spectrophotometrically, the determinations were made with Aquamate spectrophotometer.

\section{Criteria used in assessing contamination of sediments with heavy metals}

The criteria available in the literature were used to evaluate the degree to which reservoir sediments are contaminated with heavy metals. The geochemical classification of river and lake sediments devised by the Polish Geological Institute distinguishes three classes of sediment quality in line with the contents of individual elements. In order to qualify for purity class 1 , the concentrations of heavy metals in sediments may only be $2-5$ times the geochemical background level. In turn, assignment to purity classes 2 and 3 entails values $10-20$, or 20-100, times higher, respectively [Bojakowska and Sokołowska 1998].

Table 1 relates to the selected heavy metals used to assess the degree of contamination of Besko Reservoir sediments.

Contamination with heavy metals was also determined by reference to the criterion from Müller [1981], as based on the values for the geoaccumulation index $\left(\mathrm{I}_{\mathrm{geo}}\right)$ again detailing the concentrations of heavy metals in sediments against

Table 1. The geochemical classification of river and lake sediments devised by the Polish Geological Institute [Bojakowska and Sokołowska 1998]

\begin{tabular}{|l|c|c|c|c|}
\hline \multirow{2}{*}{ Heavy metal } & \multicolumn{1}{|c|}{$\begin{array}{c}\text { Geochemical } \\
\text { background }\end{array}$} & $\begin{array}{c}\text { Class 1-small } \\
\text { contamination }\end{array}$ & $\begin{array}{c}\text { Class 2-medium } \\
\text { contamination }\end{array}$ & $\begin{array}{c}\text { Class 3- large } \\
\text { contamination }\end{array}$ \\
\cline { 2 - 5 } & \multicolumn{3}{|c|}{$\mathrm{mg} \cdot \mathrm{kg}^{-1} \mathrm{~d} . \mathrm{m}}$. \\
\hline Chromium $(\mathrm{Cr})$ & 5.0 & $<20$ & $<100$ & $<100$ \\
\hline Copper $(\mathrm{Cu})$ & 6.0 & $<20$ & $<50$ & $<200$ \\
\hline Nickel $(\mathrm{Ni})$ & 5.0 & $<30$ & $<5$ & $<100$ \\
\hline Cadmium $(\mathrm{Cd})$ & $<0.5$ & $<1$ & $<1000$ & $<20$ \\
\hline Zinc $(\mathrm{Zn})$ & 48.0 & $<200$ & $<2000$ \\
\hline
\end{tabular}


the geochemical background levels. $\mathrm{I}_{\text {geo }}$ is calculated from the formula:

$$
I_{\text {geo }}=\log _{2} \frac{c_{n}}{1.5 B_{n}}
$$

where: $c_{n}$ is the concentration of the heavy metal in sediment,

$B_{n}$ is the geochemical background value for the area under analysis,

1.5 is a factor determined for lithogenesis in the catchment area, taking into account fluctuations in the content of an element in an ecosystem subject to slight anthropogenic transformation.

Table 2 shows the sediment contamination levels in line with $\mathrm{I}_{\text {geo }}$ values. The geochemical backgrounds were taken from Bojakowska and Sokołowska [1998].

The level of accumulation of heavy metals in sediments was also expressed by reference to the sediment enrichment factor (EF) used in depicting the anthropogenic contribution to heavy metals in sediments [Salomons and Förstner 1984; Wiejaczka et al. 2017]. The EF factor is calculated using the formula:

$$
E F=\frac{c_{n} B_{b}}{c_{b} B_{n}}
$$

where: $c_{n}$ is the concentration of an element in a sample,

$B_{n}$ is the geochemical background for that element,

$c_{b}$ is the reference sample content,

$B_{b}$ is the geochemical background for the reference element.

An enrichment factor was also calculated in regard to aluminium, while the geochemical background in the case of this element (17500 $\mathrm{mg} \cdot \mathrm{kg}^{-1}$ ) was that for soil, given the lack of geochemical background data relating to sediments [Szalińska et al. 2010].

The results, interpreted in line with the guidelines of Birch and Olmos [2008], are presented in Table 3 .

Sediments have also been evaluated toxicologically, in line with two Canadian guidelines involving three levels of ecotoxicity. The first criterion is based on threshold values, i.e. NEL (No Effect Level), LEL (Lowest Effect Level) and SEL (Severe Effect Level). The values for heavy metals at the NEL level are taken to indicate no toxicity for aquatic organisms, while the values below LEL relate to a level of pollution non-toxic to most organisms living in sediments. In contrast, where the SEL threshold is exceeded, there is a visible toxic effect of heavy metals on organisms, and sediment is considered highly contaminated [Persaud et al., 1993]. Another toxicological method has criteria of TEL (Threshold Effect Level) and PEL (Probable Effect Level). Exceeding TEL values for a given element implies a possible toxic effect on the living organisms, while exceeding the PEL indicates marked toxicity. The precise toxicity levels and threshold values are as shown in Table 4.

\section{RESULTS AND DISCUSSION}

The research results for the Besko Reservoir sediments are presented in Table 5 .

The sediments sampled at all research stations were slightly alkaline, with $\mathrm{pH}$ values in the narrow range 7.96-8.24. The lowest $\mathrm{pH}$ value characterised the sediments at Station 2, while the highest one was noted for Station 1, located near the dam. The contents of carbonate in the sediment were relatively high, in the range $6.12 \%$ at Station 2 to $13.23 \%$ at Station 1 . The $\mathrm{pH}$ values and carbonate contents were correlated $\left(\mathrm{R}^{2}=\right.$ 0.864). For comparison, the carbonate contents in sediments of Chańcza Reservoir were in the

Table 2. Sediment contamination levels in line with $\mathrm{I}_{\text {geo }}$ values [Müller 1981]

\begin{tabular}{|c|c|l|}
\hline Class & Value & \multicolumn{1}{|c|}{ Sediment quality } \\
\hline 0 & $\mathrm{I}_{\text {geo }} \leq 0$ & practically not contaminated \\
\hline 1 & $0<\mathrm{I}_{\text {geo }}<1$ & poorly contaminated \\
\hline 2 & $1<\mathrm{I}_{\text {geo }}<2$ & moderately contaminated \\
\hline 3 & $2<\mathrm{I}_{\text {geo }}<3$ & moderately to heavily contaminated \\
\hline 4 & $3<\mathrm{I}_{\text {geo }}<4$ & heavily contaminated \\
\hline 5 & $4<\mathrm{I}_{\text {geo }}<5$ & heavily to extremately contaminated \\
\hline 6 & $5<\mathrm{I}_{\text {geo }}$ & extremately contaminated \\
\hline
\end{tabular}

Table 3. The sediment enrichment factor (EF) in line with the guidelines of Birch and Olmos [2008]

\begin{tabular}{|l|l|}
\hline \multicolumn{1}{|c|}{ EF value } & \multicolumn{1}{c|}{$\begin{array}{c}\text { Heavy metal enrichment of } \\
\text { sediments }\end{array}$} \\
\hline$E F<1.50$ & lack of enrichment \\
\hline $1.50<E F<3.00$ & little enrichment \\
\hline $3.00<E F<5.00$ & moderate enrichment \\
\hline $5.00<E F<10.00$ & significant enrichment \\
\hline$E F>10.00$ & very strong enrichment \\
\hline
\end{tabular}


Table 4. Precise toxicity levels and threshold values [Persaud et al. 1993; MacDonald et al. 2000]

\begin{tabular}{|c|c|c|c|c|c|c|}
\hline Heavy metal & Unit & NEL & LEL & SEL & TEL & PEL \\
\hline Chromium (Cr) & \multirow{6}{*}{$\mathrm{mg} \cdot \mathrm{kg}^{-1} \mathrm{~d} \cdot \mathrm{m}$} & - & 26 & 110 & 37 & 90 \\
\hline Copper (Cu) & & - & 16 & 110 & 36 & 197 \\
\hline Nickel (Ni) & & - & 16 & 75 & 16 & 42 \\
\hline Cadmium (Cd) & & - & 0.6 & 10 & 0.7 & 3.5 \\
\hline Zinc (Zn) & & - & 120 & 820 & - & 315 \\
\hline Manganese (Mn) & & - & 460 & 1100 & 37 & 90 \\
\hline
\end{tabular}

Table 5. Research results for the Besko Reservoir sediments

\begin{tabular}{|c|c|c|c|c|c|}
\hline Parameter & Unit & Research station 1 & Research station 2 & Research station 3 & Research station 4 \\
\hline $\mathrm{pH}$ & - & 8.24 & 7.96 & 8.00 & 8.01 \\
\hline $\mathrm{CO}_{3}{ }^{2-}$ & \multirow{4}{*}{$\%$} & 13.23 & 6.12 & 7.03 & 9.76 \\
\hline OM & & 5.93 & 4.26 & 4.07 & 3.88 \\
\hline TOC & & 1.81 & 1.22 & 1.11 & 1.09 \\
\hline TN & & 0.12 & 0.07 & 0.05 & 0.06 \\
\hline C:N & - & 15 & 17 & 21 & 22 \\
\hline $\mathrm{Fe}$ & \multirow{2}{*}{$\%$} & 1.94 & 2.23 & 2.20 & 1.88 \\
\hline $\mathrm{Al}$ & & 1.85 & 1.76 & 1.77 & 1.34 \\
\hline TP & $\mathrm{mg} \cdot \mathrm{g}^{-1} \mathrm{~d} . \mathrm{m}$. & 0.832 & 0.795 & 0.773 & 0.533 \\
\hline IP & \multirow{5}{*}{$\%$} & 55.49 & 69.22 & 73.26 & 67.35 \\
\hline NAIP & & 14.34 & 8.74 & 5.01 & 18.92 \\
\hline AP & & 45.87 & 63.66 & 67.07 & 53.34 \\
\hline OP & & 24.39 & 13.91 & 7.25 & 21.60 \\
\hline $\mathrm{P}_{\mathrm{MOB}}$ & & 38.70 & 22.70 & 12.30 & 40.50 \\
\hline
\end{tabular}

2.10-3.20\% range [Tarnawski et. al. 2012], while the figures obtained for Solina and Rzeszów Reservoirs were $0.33-6.28 \%$ and $3.47-7.56 \%$, respectively [unpublished materials]. In turn, the figures for Dobczyce Reservoir were in the 0.42-3.18\% range [Wójcik 1991].

Organic matter $(\mathrm{OM})$ is a key component of sediment, but was present at the rather low level of ca. $6 \%$ d.m. at Besko. Along the length of the Reservoir, the OM contents were found to be progressively higher. Thus, the lowest $\mathrm{OM}$ value $(3.88 \%)$ characterised the upper part of the reservoir (Station 4), while the highest (5.93\%) was noted close to the dam (at Station 1). The organic carbon content (TOC) was found to correlate with that of OM $\left(\mathrm{R}^{2}=0.996\right)$. The figure for TOC was at approximately $30 \%$ of the OM value.

Sediments were also characterised by low total nitrogen (TN) contents - in the range $0.05 \%$ (Station 3) to $0.12 \%$ (Station 1). The correlations between OM and TN $\left(\mathrm{R}^{2}=0.947\right)$; as well as TOC and $\mathrm{TN}\left(\mathrm{R}^{2}=0.972\right)$, indicate that the main component of TN is organic nitrogen. The OM and TOC contents are rather typical for Polish reservoirs. For example,the sediments in Dobczyce Res- ervoir have the OM contents in the 1.76-3.13\% range, as well as TOC values of $1.02-1.82 \%$ [Wójcik 1991]. In the sediments of Rożnów Reservoir, the OM values ranged from 1-3\% [Gwóźdź and Grodecki 2011], while corresponding values elsewhere are: Sulejów 9.9-21.8\% OM and 5.2-10.3\% TOC [Bednarek and Zalewski 2007]; Czorsztyn 2.3-11.9\% OM [Haziak et al. 2013]; Solina $8.72-10.11 \%$ OM and $1.94-2.92 \%$ TOC; Myczkowce 10.78-11.94\% OM and 3.95-4.08\% TOC [Koszelnik 2009]; and Włocławek 11.5\% OM, on average [Trojanowska et al. 2009].

In fact, TOC is the main component of OM, while the quality of the latter can be expressed in terms of the TOC/TN ratio $(\mathrm{C}: \mathrm{N})$. Land plants and algae differ in their $\mathrm{C}: \mathrm{N}$ ratios, in that the values for the protein-rich algae are in the range of $4-10$, while that for cellulose-rich land plants is at or above 20 [Meyers 1997]. It is thus assumed that the $\mathrm{C}: \mathrm{N}$ ratios exceeding 12 indicate $\mathrm{OM}$ originating on land, while autochthonous organic matter has C:N values below 8 [Martinotti et al. 1997; Hellings et al. 1999]. The C:N ratio also relates to the rate at which OM is mineralised; thus, the lower the value of the ratio, the higher the rate 
of mineralisation [Trojanowska and Antonowicz 2005; Piwińska and Gruca-Rokosz 2017]. An optimum $\mathrm{C}: \mathrm{N}$ ratio for microorganisms is 17 , with the lower values indicating nitrogen release into the water table as microbial decomposition of organic matter is taking place [Sobczyński et al. 1996]. In the present study, C:N ratios are in the range of 5-22, albeit with lower values observed in the sediments further along the reservoir. The lowest $\mathrm{C}: \mathrm{N}$ value was thus recorded in the sediments at Station 1.

The results show that OM (and especially that in sediments of Besko Reservoir's upper parts) is mainly supplied from the catchment area. Sources include macrophytes and plants rich in cellulose. In turn, lower C:N values at Stations 1 and 2 indicate a greater share of autochthonous matter in sediments .

Besko Reservoir also features the contents of iron and aluminium in the ranges of $1.88-2.23 \%$ and $1.34-1.85 \%$ respectively. The sediment contents of these heavy metals are lowest at Station 4, while the peak for aluminium is at Station 1. In turn, the highest iron content characterised the sediments from Station 2. These values are similar to one obtained in the sediments of other Polish reservoirs [Czerwieniec et al. 2003; GIOŚ 2016].

In contrast, the Besko sediments have contents of total phosphorus slightly above those in other reservoirs. Their values were in the range from $0.533 \mathrm{mg} \cdot \mathrm{g}^{-1} \mathrm{~d} . \mathrm{m}$. at Station 4 to $0.832 \mathrm{mg} \cdot \mathrm{g}^{-1}$ d.m. at Station 1 (Table 5). These values also conform an upward trend when the backwater of the Reservoir is compared with the site near the water dam. Elsewhere, the values for phosphorus in reservoir sediments expressed in $\mathrm{mg} \cdot \mathrm{g}^{-1} \mathrm{~d} . \mathrm{m}$. were $0.22-0.44$ at Krempna; $0.37-0.40 \mathrm{mg} \cdot \mathrm{g}^{-1} \mathrm{~d}$.m. at Zesławice and 0.34 at Dobczyce [Tarnawski et al. 2012]. The analysis of phosphorus fractionation showed the dominant contribution of the inorganic form (IP) in the sediments at all Stations (albeit with the values ranging from $55.49 \%$ at Station 1 to $73.26 \%$ at Station 3). No similar trends have been observed. Organic phosphorus (OP) was present at the percentages of total $\mathrm{P}$ between $7.25 \%$ (at Station 3) and 24.39\% (at Station 1). In turn, inorganic phosphorus consists of NAIP and AP fractions, the respective contributions of which are $5.01-18.92 \%$ and $45.87-67.07 \%$. The smallest NAIP and highest AP characterised the sediments at Station 3. The proportion of IP was evidently affected by apatite phosphorus (AP) $\left(\mathrm{R}^{2}\right.$ $=0.860)$. The lowest share of the NAIP fraction is taken to indicate a limited anthropogenic influence in the catchment area, including the inflows of wastewater. In the sediments of the Bort-LesOrgues Reservoir (France), the percentages noted for the OP; NAIP and AP fractions were 25\%; $59 \%$ and $16 \%$ respectively [Ruban et al. 1999]. In turn, the sediments of the Solina Reservoir were found to have ca. $63 \%$ IP; $34 \%$ OP; $24 \%$ NAIP and $39 \%$ AP [Bartoszek and Tomaszek 2011].

At Besko, the highest percentage noted for mobile phosphorus (i.e. NAIP + OP) was $40.5 \%$ at Station 4. Correspondingly, the lowest percentage characterised the sediments at Station 3. The content of mobile phosphorus is important, given that it determines the bioavailability of phosphorus forms. In fact, the sediments of Besko Reservoir look poor in mobile phosphorus when compared with other reservoirs. Here, the internal supply of phosphates is impossible due to the low content of total phosphorus, mobile phosphorus and organic matter.

The qualitative analysis of heavy-metal contamination in the Besko Reservoir sediments is useful in helping to determine the distribution of these elements, potentially even with the sediments being put to use once extracted. As far as heavy metals are concerned, the results of the analysis are in Table 6.

In practice, each heavy metal was found to be present at rather similar levels in sediments at the different research stations. The contents of chromium were highest vis-à-vis the geochemical background (at 38.42-46.28 mg $\mathrm{kg}^{-1}$ d.m.).

Table 6. The results of the analysis pertaining to heavy metals

\begin{tabular}{|c|c|c|c|c|c|}
\hline Heavy metal & Unit & Research station 1 & Research station 2 & Research station 3 & Research station 4 \\
\hline Chromium (Cr) & \multirow{6}{*}{$\mathrm{mg} \cdot \mathrm{kg}^{-1} \mathrm{~d} . \mathrm{m}$. } & 38.42 & 44.43 & 46.28 & 40.24 \\
\hline Copper (Cu) & & 31.78 & 24.82 & 25.53 & 24.48 \\
\hline Nickel (Ni) & & 29.16 & 30.49 & 31.19 & 35.28 \\
\hline Cadmium (Cd) & & 0.42 & 0.67 & 0.65 & 1.25 \\
\hline Zinc (Zn) & & 79.76 & 81.85 & 75.75 & 78.61 \\
\hline Manganese $(\mathrm{Mn})$ & & 311.58 & 337.20 & 383.90 & 438.29 \\
\hline
\end{tabular}


Similar values for chromium and copper were recorded in sediments of Zesławice Reservoir (29.9 mg Cr$\cdot \mathrm{kg}^{-1}$ d.m.; $7.7 \mathrm{mg} \mathrm{Cu} \cdot \mathrm{kg}^{-1}$ d.m.), Majdan Sopocki Reservoir (34.8 mg Cr $\mathrm{kg}^{-1}$ d.m.; 11.8 $\mathrm{mg} \mathrm{Cu} \cdot \mathrm{kg}^{-1}$ d.m.) [Madeyski and Tarnawski 2006] and Rzeszów Reservoir (41.74 $\mathrm{mg} \mathrm{Cr} \cdot \mathrm{kg}^{-1} \mathrm{~d} . \mathrm{m}$.; $29.54 \mathrm{mg} \mathrm{Cu} \cdot \mathrm{kg}^{-1} \mathrm{~d} . \mathrm{m}$.) [unpublished materials]. The catchment areas of all these reservoirs are agricultural and forested [WIOŚ 2017; www.pzw. org.pl]. In contrast, significantly higher concentrations of chromium and copper were observed in the sediments of Włocławek Reservoir (330 mg Cr $\cdot \mathrm{kg}^{-1}$ d.m.; $55.8 \mathrm{mg} \mathrm{Cu} \cdot \mathrm{kg}^{-1}$ d.m.) [Gierszewski 2008] and Rybnik Reservoir (140 mg $\mathrm{Cr} \cdot \mathrm{kg}^{-1}$ d.m.; $1000 \mathrm{mg} \mathrm{Cu} \cdot \mathrm{kg}^{-1} \mathrm{~d}$.m.) [Madeyski and Tarnawski 2006].

The seduments of Besko Reservoir are seen to support relatively high concentrations of nickel. Only Rybnik Reservoir has reported a higher value $\left(55.0 \mathrm{mgNi} \cdot \mathrm{kg}^{-1} \mathrm{~d} . \mathrm{m}\right.$.). In contrast, the concentrations of cadmium and zinc at Besko are such as to suggest only slight sediment contamination as compared with what can be noted in other reservoirs. For example, the respective concentrations of cadmium are 10 and 25 times higher in the sediments of Włocławek and Rybnik Reservoirs than in those at Besko [Gierszewski 2008; Madeyski and Tarnawski 2006]. In turn, Zesławice Reservoir reported a lower content of zinc $(72.6 \mathrm{mg}$ $\mathrm{Zn} \cdot \mathrm{kg}^{-1}$ d.m.) [Madeyski and Tarnawski 2006].
In line with the classification of sediments prepared at the Polish Geological Institute, those at Besko can be categorised as $2^{\text {nd }}$-class purity. In turn, applying the Müller criterion, only $3^{\text {rd }}$-class purity is achieved, which is to say that sediments are moderately to heavily contaminated. This is particularly the case given the observed values for the geoaccumulation index related to chromium and nickel (Table 7).

Heavy-metal enrichment of sediments expressed using factor EF is as presented in Table 8.

Metal-ion enrichment was in the order $\mathrm{Cr}>\mathrm{Ni}>\mathrm{Cu}>\mathrm{Zn}>\mathrm{Cd}>\mathrm{Mn}$ in the sediments at Stations 1-3. In turn, Station 4 was characterised by the order $\mathrm{Cr}>\mathrm{Ni}>\mathrm{Cu}>\mathrm{Cd}>\mathrm{Zn}>\mathrm{Mn}$. The highest EF value (of 10.29) was noted in the case of chromium in sediments at Station 4.

In line with the ecotoxicological criteria, chromium, nickel and cadmium may all prove potentially toxic to the living organisms ( $>$ LEL, TEL). Copper $(>$ TEL) and zinc $(<$ PEL) also exhibit toxicity.

Under the Regulation of the Minister of the Environment of the Republic of Poland of $11^{\text {th }}$ May 2015 on the recovery of waste beyond installations, sediments should not be seen as contaminated in terms of the contents of some heavy metals studied. This ensures a potential use for these sediments, for example in the building and maintenance of hydraulic structures like wharves, embankments, etc.; or in surface hardening.

Table 7. Purity classes in line with $\mathrm{I}_{\text {geo }}$ values

\begin{tabular}{|c|c|c|c|c|c|}
\hline Heavy metal & $\begin{array}{l}\text { Geochemical } \\
\text { background } \\
{\left[\mathrm{mg} \cdot \mathrm{kg}^{-1} \mathrm{~d} . \mathrm{m} .\right]}\end{array}$ & Research station 1 & Research station 2 & Research station 3 & Research station 4 \\
\hline Chromium (Cr) & 5.0 & 3 & 3 & 3 & 3 \\
\hline Copper (Cu) & 6.0 & 2 & 2 & 2 & 2 \\
\hline Nickel (Ni) & 5.0 & 2 & 3 & 3 & 3 \\
\hline Cadmium (Cd) & $<0.5$ & 0 & 0 & 0 & 1 \\
\hline Zinc (Zn) & 48.0 & 1 & 1 & 1 & 1 \\
\hline Manganese (Mn) & 850.0 & 0 & 0 & 0 & 0 \\
\hline
\end{tabular}

Table 8. Heavy-metal enrichment of sediments expressed using factor EF

\begin{tabular}{|l|c|c|c|c|}
\hline \multicolumn{1}{|c|}{ Heavy metal } & Research station 1 & Research station 2 & Research station 3 & Research station 4 \\
\hline Chromium (Cr) & 7.29 & 8.81 & 9.17 & 10.49 \\
\hline Copper $(\mathrm{Cu})$ & 5.02 & 4.10 & 4.21 & 5.32 \\
\hline Nickel $(\mathrm{Ni})$ & 5.53 & 6.05 & 6.17 & 9.19 \\
\hline Cadmium $(\mathrm{Cd})$ & 0.80 & 1.33 & 1.29 & 3.26 \\
\hline Zinc $(\mathrm{Zn})$ & 1.58 & 1.69 & 1.56 & 2.13 \\
\hline Manganese $(\mathrm{Mn})$ & 0.34 & 0.39 & 0.45 & 0.67 \\
\hline
\end{tabular}




\section{CONCLUSIONS}

The conclusions to be drawn from analysis of the sediments in Poland's Besko Reservoir are as follows:

- the sediment reaction is slightly alkaline, with $\mathrm{pH}$ values in the range of 7.96-8.24, as correlated with a high $6.12-13.23 \%$ carbonate content $\left(\mathrm{R}^{2}=0.864\right)$;

- sediments are of low (approx. 6\%) organic matter content, with $\mathrm{C}: \mathrm{N}$ ratios of $15-22$, indicative of an allochthonous origin of organic matter, and with lower values towards the dam associated with progressively higher OM content;

- the IP fraction is the dominant phosphorus fraction in sediments, while the lowest values within total P characterise the NAIP fraction (perhaps on account of the resuspension of sediments and a zero or limited inflow from anthropogenic sources);

- in line with the PIG criterion, sediments at Besko are of $2^{\text {nd }}$-class purity; while under the Müller classification they are in $3^{\text {rd }}$ class (suggesting moderately or heavily contaminated sediment); in turn, EF coefficient values show very strong enrichment of chromium ions; while ecotoxicity criteria suggest that the contents of chromium, copper, nickel and cadmium are sufficient to indicate potential toxicity to the living organisms;

- sediments are nonetheless utilisable, due to their limited contents of heavy metals, for example in the construction and maintenance of hydraulic structures or else in surface hardening.

\section{REFERENCES}

1. Bartoszek L., Tomaszek J.A. 2011. Analysis of the spatial distribution of phosphorus fractions in the bottom sediments of the Solina-Myczkowce dam reservoir complex. Environment Protection Engineering, 37(3), 5-15.

2. Bednarek A., Zalewski M. 2007. Potential effects of enhancing denitrification rates in sediments of the Sulejów Reservoir. Environment Protection Engineering, 33(2), 35-43.

3. Birch G.F., Olmos M.A. 2008. Sediment-bound heavy metals as indicators of human influence and biological risk in coastal water bodies. ICES Journal of Marine Science, 65(8), 1407-1413.

4. Bojakowska I., Sokołowska G. 1998. Geochemi- cal class purity of water sediments (in Polish). Przegląd Geologiczny, 46(1), 49-54.

5. Czerwieniec E., Gruca-Rokosz R., Bartoszek L., Tomaszek J. 2003. Chemical composition of bottom sediment in Rzeszów reservoir (in Polish). III Ogólnopolska Konferencja Naukowo-Techniczna „Postęp w Inżynierii Środowiska”, RzeszówPolańczyk, 303-309.

6. Gierszewski P. 2008. The concentration of heavy metals in sediments of the Wloclawek Reservoir as an indicator of hydrodynamic conditions of deposition (in Polish). Landform Analysis, 9, 79-82.

7. Gwóźdź R., Grodecki M. 2011. The possibility of using cohesive soils of Rożnowskie Lake in the construction of the hydraulic embankment - an analysis (in Polish). Czasopismo Techniczne, 2-Ś/2011, Wydawnictwo Politechniki Krakowskiej.

8. Haziak T., Czaplicka-Kotas A., Ślusarczyk Z., Szalińska E. 2013. Spatial changes of zinc concentrations in the Czorsztyn Reservoir sediments (in Polish). Inżynieria i Ochrona Środowiska, 16(1), 57-68.

9. Hellings L., Dehairs F., Tackx M., Keppens E., Baeyens W. 1999. Origin and fate of organic carbon in the freshwater part of the Scheldt Estuary as traced by stable carbon isotope composition. Biogeochemistry, 47, 167-186.

10. Koszelnik P. 2009. Sources and distribution of biogenic elements on the example of the Solina-Myczkowce dam reservoir (in Polish). Oficyna Wydawnicza Politechniki Rzeszowskiej, Rzeszów, 1-147.

11. MacDonald D.D., Ingersoll C.G., Berger T.A. 2000. Development and evaluation of consensusbased sediment quality guidelines for freshwater ecosystems. Archives of Environmental Contamination and Toxicology, 39, 20-31.

12. Madeyski M., Michalec B., Tarnawski M. 2008. Silting of small water reservoirs and quality of sediments (in Polish). Infrastruktura i ekologia terenów wiejskich, 11-22.

13. Martinotti W., Camusso M., Guzzi L., Patrolecco L., Pettine M. 1997. C, N and their stable isotopes in suspended and sedimented matter from the Po estuary (Italy). Water, Air and Soil Pollution, 99, 325-332.

14. Meyers P.A. 1997. Organic geochemical proxies of paleoceanographic, paleolimnologic, and paleoclimatic processes. Organic Geochemistry, 27(5-6), $13-250$.

15. Müller G. 1981. Heavy metal burden of the Neckar and its tributaries (in German). Chemiker-Zeitung, 6, 157-164.

16. Ostrowska A., Gawliński S., Szczubiałka Z. 1991. Methods of analysis and evaluate of soil and plant properties (in Polish). Instytut Ochrony Środowiska, Warszawa. 
17. Persaud D., Jaagumagi R., Hayton A. 1993. Guidelines for the Protection and Management of Aquatic Sediment Quality in Ontario. Ontario Ministry of the Environment, Toronto, 1-39.

18. Piwińska D., Gruca-Rokosz R. 2016. Indicators of origin and directions of transformation of organic matter in sediments of water reservoirs (in Polish). Czasopismo Inżynierii Lądowej, Środowiska i Architektury JCEEA, XXXIV, 64(1/17), 23-33.

19. Ruban V., Brigault S., Demare D., Philipe A.-M. 1999. An investigation of the origin and mobility of phosphorus in freshwater sediments from BortLes-Orgues Reservoir, France. J. Environ. Monit., 1, 403-407,.

20. Ruban V., Lopez-Sanchez J.F., Padro P., Rauret G., Muntau H., Quevauviller Ph. 2001. Development of a harmonized phosphorus extraction procedure and certification of a sediment reference material. Journal of Environmental Monitoring, 3, 121-125.

21. Salomons W., Förstner U. 1984. Metals in the Hydrocycle. Springer-Verlag, Berlin.

22. Sobczyński T., Zerbe J., Elbanowska H., Sajewska K., Siepak J. 1996. Chemical examinations of bottom sediments of Wielkopolski National Park lakes regarding anthropopression (in Polish). Ekol. Tech., 5(7), 17-22.

23. Szalińska E., Koperczak A., Czaplicka-Kotas A. 2010. Heavy metals in the bottom sediments of Lake Goczalkowickie tributaries (in Polish). Ochrona Środowiska, 32(1), 21-25.

24. Szarek-Gwiazda E. 2013. Factors influencing the concentrations of heavy metals in the Raba River and selected Carpathian dam reservoirs (in Polish). Studia Naturae, 60, 1-146.

25. Tarnawski M., Baran A., Jasiewicz C. 2012. As- sessment of physicochemical properties of the bottom sediments Chańcza reservoir (in Polish). Proceedings of ECOpole, 6(1), 305-311.

26. Trojanowska J., Antonowicz J. 2005. Chemical characteristics of bottom sediments in Dołgie Wielkie Lake (in Polish). Słupskie Prace Biologiczne, 2, 123-127.

27. Trojanowska A., Kurasiewicz M., Pleśniak Ł. Jędrysek M. O. 2009. Emission of methane from sediments of selected Polish dam reservoir. Teka Kom. Ochr. Środ. Przyr.-OL PAN, 6, 368-373.

28. Wiejaczka Ł., Prokop P., Kozłowski R., Sarkar S. 2017. Impact of a dam reservoir on the chemistry of a Himalayan River (the Teesta, India) (in Polish). Przegląd Geograficzny, 89(1), 165-181.

29. WIOŚ Rzeszów. 2017. Protection of water reservoirs against pollution (in Polish). Raport z realizacji wojewódzkiego cyklu kontrolnego realizowanego w latach 2015-2016.

30. Wójcik D. 1991. Characterization of the bottom sludge of the Dobczyce Reservoir (in Polish). Ochrona Środowiska, 1(42), 31-34.

31. Zimmermann C. F., Keefe C. W., Bashe J. 1997. Determination of carbon and nitrogen in sediments and particulates/coastal waters using elemental analysis. Method 440.0. NER Laboratory, USEPA, Cincinnati, Ohio, http://www.epa.gov/nerlcwww/ m440_0.pdf

32. http://www.krakow.rzgw.gov.pl/index. php?option $=$ com_content $\&$ view $=$ article $\&$ id $=111$ : zbiornik-wodny-besko\&catid=40\&Itemid=239\&1 ang $=\mathrm{pl}$

33. http://www.pzw.org.pl/wydra/cms/9189/majdan_ sopocki

34. http://www.gios.gov.pl/ GIOŚ 2016 